Original Research Paper

\title{
Pendampingan Guru Biologi dalam Penyusunan Instrumen Penilaian Berorientasi HOTS di Kabupaten Lombok Barat
}

\author{
Gito Hadiprayitno $^{1 *}$, Muhlis ${ }^{2}$, I Putu Artayasa ${ }^{3}$ \\ 1,2,3 Program Studi Pendidikan Biologi FKIP Universitas Mataram, Jl. Majapahit 62 Mataram - NTB 83125
}

DOI: https://doi.org/10.29303/jpmpi.v3i2.512

Sitasi : Hadiprayitno, G., Muhlis., \& Artayasa, I. P. (2020). Pendampingan Guru Biologi dalam Penyusunan Instrumen Penilaian Berorientasi HOTS di Kabupaten Lombok Barat. Jurnal Pengabdian Magister Pendidikan IPA, 3(2)

\author{
Article history \\ Received: 30 September 2020 \\ Revised: 14 Oktober 2020 \\ Accepted: 19 November 2020 \\ *Corresponding Author: \\ Gito Hadiprayitno, \\ Program Studi \\ Pendidikan Biologi, Fakultas \\ Keguruan dan Ilmu Pendidikan, \\ Universitas Mataram, \\ Indonesia. \\ Email: \\ gitohadiprayitno@unram.ac.id
}

\begin{abstract}
Telah dilakukan kegiatan pendampingan pada guru Biologi dalam penyusunan instrumen penilaian berorientasi HOTS di Kabupaten Lombok Barat. Kegiatan pendampingan guru dalam penyusunan instrumen penilaian berorientasi HOTS ini dilaksanakan dalam bentuk (1) penyampaian materi secara klasikal, (2) pemberian contoh dalam membuat soal HOTS, dan (3) pendampingan guru dalam menyusun instrumen penilaian HOTS. Sebelum penyampaian materi dan latihan diberikan, terlebih dahulu dilakukan Survei dengan menggunakan angket. Hasil survei menunjukkan bahwa sebagian besar (55\%) guru biologi yang ada di Kabupaten Lombok Barat belum pernah mengikuti kegiatan pelatihan pembuatan instrumen penilaian yang berorientasi HOTS. Semua guru $(100 \%)$ setuju dan bersedia diberikan pelatihan terkait dengan HOTS. Kegiatan pelatihan dilaksanakan secara daring menggunakan zoom meeting. Peserta pelatihan terdiri dari 39 orang guru. Sebagian besar guru yang ikut pelatihan $(52 \%)$ berasal dari Pulau Lombok. Sementara itu sisanya, 28\% guru berasal dari Pulau Bali dan 20\% guru berasal dari Pulau Sumbawa. Hasil pelatihan dan pendampingan menunjukkan bahwa guruguru biologi yang ada di Kabupaten Lombok Barat masih mengalami kesulitan dalam pembuatan stimulus. Faktor penyebab guru mengalami kesulitan diantaranya disebabkan oleh kemampuan literasi dasar sekitar 30 - 40\% dan kesulitan dalam melakukan kegiatan pengembangan media sekitar 50\%. Karena itu, kegiatan pendampingan lanjutan yang melibatkan forum MGMP masih diperlukan.
\end{abstract}

Keywords: Penilaian, Berpikir, Tingkat Tinggi, Biologi

\section{Pendahuluan}

$\mathrm{P}^{\mathrm{e}}$ erubahan kurikulum dalam dunia pendidikan yang terjadi pada dekade 10 tahun terakhir ini mengakibatkan terjadinya penyempurnaan dari banyak aspek. Perubahan kurikulum yang agak sedikit dramatis terjadi pada tahun 2013. Pemberlakukan kurikulum 2013 ini menimbulkan banyak kontroversi karena ketidaksiapan dari para pelaku khususnya guru dalam mengimplementasikan pada proses pembelajaran. Salah satu bentuk penyempurnaan yang telah dilakukan ialah pengurangan terhadap materi pelajaran yang tidak relevan dan digantikan dengan pengembangan materi yang menuntut kemapuan berpikir kritis dan analitis yang disesuaikan dengan kondisi saat ini (Wahyuningtyas \& Ratnawati, 2018). Disamping itu juga terjadi penyempurnaan pada standar penilaian dengan mengacu pada 
standar penilaian internasional. Salah satu hal penting yang dituntut dalam penilaian pembelajaran menurut Kemendikbud (2018) ialah peningkatan kemampuan berpikir tinggi (High Order Thinking Skills/HOTS). Tuntutan penilaian seperti ini memberikan dorongan kepada peserta didik untuk berpikir secara mendalam dan tidak terpaku pada buku teks pelajaran semata (Devi, 2012; Hanifah, 2019).

Kondisi tersebut di atas didasari atas hasil studi yang dilakukan oleh PISA (Programme for International Student Assesment) yang menyatakan bahwa kemapuan literasi sains peserta didik yang ada di Indonesia masih sangat rendah dan berada di bawah rata-rata internasional. Sebagian besar siswa yang ada di Indonesia mengalami kesulitan dalam mengerjakan soal-soal yang terakit dengan penalaran (Kemendikbud, 2017). Lebih lanjut Ayuningtyas (2016) menyatakan bahwa sebagian besar siswa yang ada di Indonesia terbiasa dalam mengerjakan soal-soal yang dikategorikan ke dalam kemampuan mengingat dan menghafal. Kecenderungan tersebut dapat terjadi karena sebagian besar guru dalam membuat soal yang digunakan dalam kegiatan penilaian pembelajaran jarang yang dikaitkan dengan indikator menganalisis, mengevaluasi, dan mencipta.

Situasi dan kondisi yang sudah diungkapkan tersebut memberikan gambaran bahwa sebagian besar guru memiliki kompetensi yang rendah dalam mengembangkan soal yang berorientasi pada HOTS (Zaini, 2015). Mengacu pada Taksonomi Bloom bahwa indikator soal yang terkait dengan kemampuan menganalisis, mengevaluasi, dan mencipta merupakan soal yang menuntut siswa untuk berpikir tingkat tinggi (Anderson \& Krathwohl, 2001). Karena itu, guru dituntut memiliki kemampuan yang mumpuni dalam mengembangkan soal HOTS untuk mengembangkan kemampuan berpikir kritis siswa (Wahyuningtyas \& Ratnawati, 2018). Kondisi seperti ini terjadi pada semua guru biologi tidak terkecuali guru biologi yang ada di Pulau Lombok.

Hasil penelitian yang dilakukan oleh Hadiprayitno et al (2019) menunjukkan bahwa sebagian besar siswa ( $\geq 70 \%)$ mengalami kesulitan dalam belajar materi biologi. Kesulitan ini sejalan dengan kesulitan guru dalam mengembangkan instrumen penilaian. Lebih dari $54 \%$ guru biologi yang ada di Pulau Lombok memiliki kesulitan dalam mengembangkan istrumen penilaian. Hasil observasi lebih lanjut pada guru biologi yang tergabung dalam Forum MGMP (Musyawarah Guru Mata Pelajaran) yang ada di Kabupaten Lombok Barat menunjukkan bahwa hanya $10 \%$ guru biologi yang memiliki kemampuan dalam mengidentifikasi soal-saol berorientasi HOTS. Akan tetapi, belum memiliki kemampuan dalam menyusun soal HOTS dengan benar. Sementara itu, sebagian besar guru biologi (90\%) belum pernah mendapatkan pelatihan pembuatan soal HOTS sehingga memiliki pengetahuan yang minim terkait dengan hal tersebut.

Berdasarkan pada analisis situasi tersebut, perlu dilakukan kegiatan pendampingan terhadap guru-guru biologi yang ada di Kabupaten Lombok Barat dalam meningkatkan pengetahuan dan kemampuannya dalam menyusun dan mengembangkan soal-soal (instrumen) penilaian berorientasi HOTS. Pendampingan seperti ini diharapkan dapat membantu guru dalam meningkatkan kualitas pembelajaran melalui kegiatan penyusunan instrumen penilaian yang menuntut kemampuan kognitif siswa pada tingkatan menganalisis, mengevaluasi, dan mencipta. Kemampuan berpikir tingkat tinggi seperti ini sangat diperlukan dalam era revolusi industri 4.0 dan era disrupsi yang terjadi pada saat sekarang ini.

\section{Metode}

Kegiatan pendampingan guru dalam penyusunan instrumen penilaian berorientasi HOTS dilaksanakan dalam bentuk (1) penyampaian materi secara klasikal, (2) pemberian contoh dalam membuat soal HOTS, dan (3) pendampingan guru dalam menyusun instrumen penilaian HOTS. Namun demikian, sebelum penyampaian materi dan latihan diberikan, terlebih dahulu dilakukan survei analisis kebutuhan penyusunan instrumen penilaian berorientasi HOTS kepada guru-guru biologi yang ada di Kabuoaten Lombok Barat. Survei dilakukan dengan menggunakan angket. Hasil survei ini 
dimantapkan lebih lanjut melalui kegiatan FGD. Hal ini dilakukan untuk memastikan bahwa permasalahan yang dihadapi oleh guru biologi merupakan permasalahan bersama yang harus dicarikan jalan keluarnya. Hasil survei dan FGD ini dijadikan sebagai dasar dalam memberikan materi pelatihan yang akan dilakukan secara klasikal.

Penyampaian materi secara klasikal dilakukan dengan menghadirkan semua guru biologi yang tergabung dalam Forum MGMP yang ada di Kabupaten Lombok Barat. Peyampaian materi ini dilakukan secara daring menggunakan zoom meeting. Penyampaian materi dihadiri juga oleh guru-guru yang berasal dari daerah lain seperti guru-guru yang mengajar di Pulau Sumbawa dan Pulau Bali. Hal-hal penting yang disampaikan dalam kegiatan webinar terdiri dari (1) konsep penyusunan soal HOTS, (2) Teknik penyusunan soal beorientasi HOTS, (3) analisis kompetensi dasar dikembangkan menjadi indikator soal HOTS, (4) penyusunan dan pendampingan guru dalam mengembangkan soal HOTS, dan (5) evaluasi soal yang berorientasi HOTS.

Pada akhir kegiatan penyampaian materi secara klasikal, semua peserta diberikan tugas untuk membuat soal berorientasi HOTS dengan mengacu pada RPP yang pernah disampaikan dalam kegiatan pembelajaran. Pembahasan dan pendampingan guru dalam menyelesaikan tugas ini dilakukan dengan cara setiap peserta menyampaikan atau mempresentasikan tugas-tugas yang diberikan, peserta lain mengkritisi dan memberikan masukan untuk penyempurnaan terhadap tugas yang diberikan. Tim pengabdian memberikan umpan balik dengan cara mereview lebih lanjut dengan cara memastikan bahwa tugastugas yang dikerjakan oleh guru biologi sudah sesuai dengan ketentuan soal HOTS. Pembuatan soal-soal HOTS yang dibuat oleh guru ini mengacu pada buku panduan yang dibuat oleh tim pengabdian.

\section{Hasil dan Pembahasan}

\section{Analisis Kebutuhan Pelatihan Penilaian Berorientasi HOTS}

Berdasarkan hasil survei (Gambar 1) dengan menggunakan kuesioner menunjukkan bahwa sebagian besar $(55 \%)$ guru biologi yang ada di Kabupaten Lombok Barat belum pernah mengikuti kegiatan pelatihan pembuatan instrumen penilaian yang berorientasi HOTS. Akan tetapi meskipun $45 \%$ guru biologi pernah mengikuti kegiatan pelatihan, semua guru $(100 \%)$ setuju dan bersedia diberikan pelatihan terkait dengan HOTS. Beberapa alasan yang menguatkan kesediaan guru dalam mengikuti kegiatan pelatihan tersebut diantaranya (1) $53 \%$ guru masih belum memahami dalam mengembangkan indikator soal yang berorientasi HOTS, (2) Penyusunan instrumen berorientasi HOTS sangat penting dalam penyusunan soal pembelajaran, (3) Instrumen soal berorientasi HOTS membantu siswa meningkatkan kemampuan berpikir kritis dalam pemecahan masalah, (4) Guru biologi perlu menggunakan instrumen soal berorientasi HOTS dalam evalusi pembelajaran, dan (5) Guru biologi perlu menyampaikan indikator soal berorientasi HOTS kepada siswa.

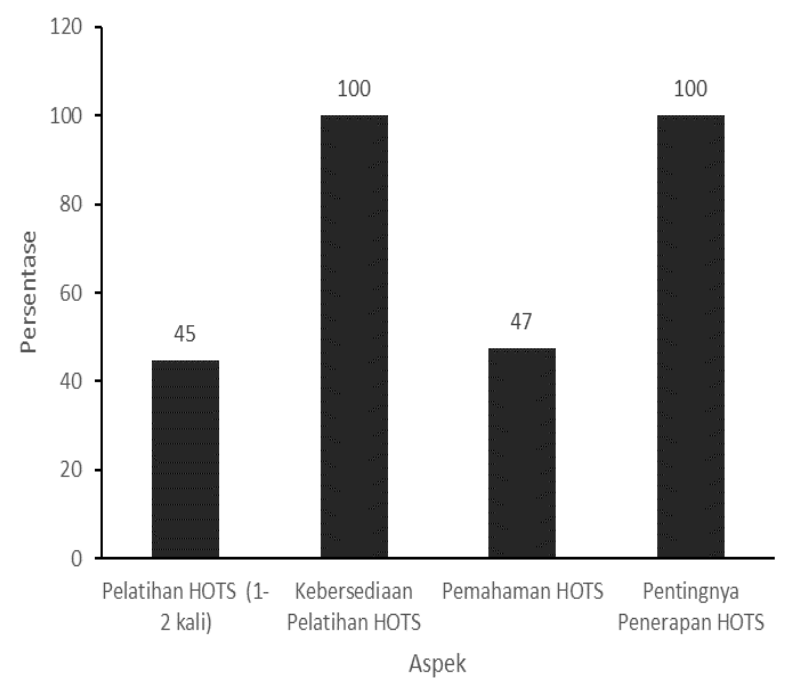

Gambar 1. Hasil Analisis Kebutuhan Pelatihan HOTS pada Guru Biologi

Hasil angket juga memberikan informasi bahwa sebagian besar guru salah menafsirkan bahwa soal HOTS merupakan soal yang sulit. Padahal soal sulit belum tentu soal HOTS, demikian pula sebaliknya 'Difficulty' is NOT the same as the higher order thinking." Kalimat sederhana ini bermakna bahwa soal yang sulit tidaklah sama dengan soal HOTS. Kenyataannya, baik soal LOTS maupun HOTS, keduanya memiliki rentang tingkat kesulitan yang sama dari yang mudah, sedang dan sulit. Dengan kata lain, ada soal 
LOTS yang mudah dan ada juga soal HOTS yang mudah, demikian juga dengan tingkat kesulitan yang tinggi ada juga pada soal LOTS. Sebagai contoh, untuk mengetahui arti sebuah kata yang tidak umum (uncommon word) mungkin memiliki tingkat kesukaran yang sangat tinggi karena hanya sedikit siswa yang mampu menjawab benar, tetapi kemampuan untuk menjawab permasalahan tersebut tidak termasuk higher order thinking skills. Sebaliknya sebuah soal yang meminta siswa untuk menganalisa dengan melakukan pengelompokan benda berdasarkan ciri fisik bukan merupakan soal yang sulit untuk dijawab oleh siswa.

\section{Pelatihan Instrumen Penilaian Berorientasi HOTS}

Kegiatan pelatihan instrumen penilaian berorientasi HOTS dilaksanakan pada tanggal 19 Agustus 2020. Kegiatan pelatihan dilaksanakan secara daring menggunakan zoom meeting. Peserta pelatihan terdiri dari 39 orang guru (Gambar 2). Sebagian besar guru yang ikut pelatihan (52\%) berasal dari Pulau Lombok. Sementara itu sisanya, $28 \%$ guru berasal dari Pulau Bali dan 20\% guru berasal dari Pulau Sumbawa.

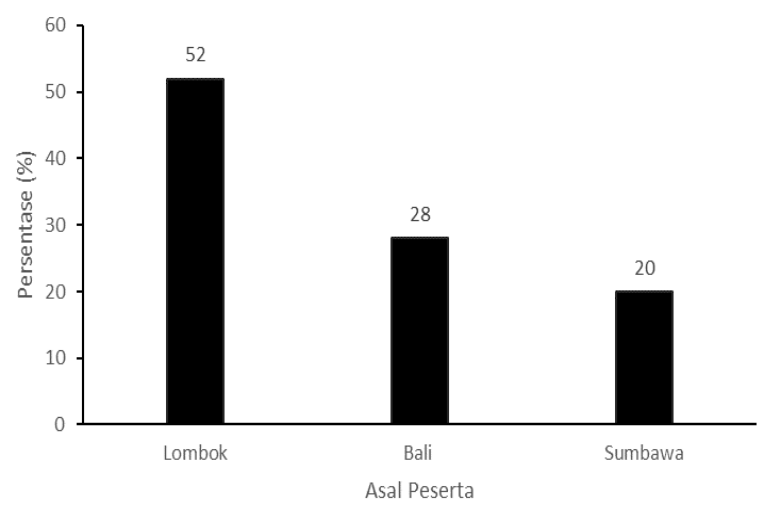

Gambar 2. Peserta Pelatihan Instrumen Penilaian Berorientasi HOTS

Materi pelatihan terdiri dari konsep
instrumen penilaian berorientasi HOTS,
karakteristik soal HOTS, alur penyusunan soal
HOTS, dan pemberian contoh soal HOTS. Soal
HOTS merupakan instrumen pengukuran yang
digunakan untuk mengukur keterampilan berpikir
tingkat tinggi (Widiana, 2017). Keterampilan

berpikir tingkat tinggi menuntut siswa untuk mengkaitkan konsep yang satu dengan konsep yang lain, mengintegrasikan berbagai informasi untuk menyelesaikan masalah, serta menelaah ide dan informasi secaa kritis sebelum mengambil keputusan. Karena itu, guru dalam mengembangkan instrumen penilaian berorientasi HOTS harus memiliki kemampuan dalam membuat suatu stimulus yang dapat merangsang siswa untuk menelaah dan menganalisis permasalahan yang sedang dihadapi. Stimulus ini merupakan dasar berpijak untuk memahami informasi. Stimulus harus bersifat kontekstual dan menarik siswa untuk ditelaah. Berdasarkan kajian pada beberapa referensi diantaranya ialah Widiana (2017) stimulus dalam soal HOTS dapat berupa pengembangan konsep, tokoh, lingkungan sekolah, dan isu-isu global. Sehubungan dengan hal tersebut, guru yang akan mengembangkan stimulus dalam pembuatan instrumen penilaian berorientasi HOTS harus memiliki kemampuan dalam bidang literasi digital yang baik. Literasi digital ini memungkinkan guru dalam pengembangan stimulus yang diperoleh dari referensi terkini dan kontekstual. Stimulus yang dikembangkan dengan cara seperti ini akan menantang siswa untuk menyelesaikan permasalahan-permasalahan yang sedang dihadapi karena bersifat kontekstual dan terkait langsung dengan permasalahan yang ditemukan dalam kehidupan sehari-hari.

Pada penyampaian materi yang dilakukan secara daring ini, muncul pertanyaan dari guru-guru biologi terkait dengan karakteristik soal HOTS. Sebagian besar guru mengalami kesulitan dalam mengidentifikasi soal-soal HOTS ini. Selama ini soal-soal yang sulit dijawab oleh siswa dianggap sebagai soal HOTS. Beberapa karakteristik soal HOTS yang disampaikan untuk menjawab permasalahan ini diantaranya ialah (1) soal HOTS mengukur keterampilan berpikir tingkat tinggi (problem solving, berpikir kreatif, dan berpikir inovatif); (2) basis pembuatan soal HOTS bersifat kontekstual (stimulus dibuat dengan mengacu pada informasi terkini yang sedang menjadi trending topic); dan (3) soal HOTS merupakan soal yang tidak diujikan berulang-ulang pada peserta didik yang sama harus dapat mengusung kebaruan. Sehubungan dengan hal tersebut dalam melakukan 
penyusunan soal HOTS harus mengikuti alur sebagai berikut (1) melakukan analisis KD (kompetensi dasar), tidak semua KD bisa dijadikan sebagai soal HOTS, tagihan soal HOTS terkait dengan KD pada level kognitif C4 - C6; (2) menyusun kisi-kisi soal; (3) menyusun stimulus; (4) menyusun soal HOTS; dan (5) membuat kunci jawaban dan pedoman penskoran. Langkah-langkah penyusunan soal HOTS, disajikan lebih lanjut pada Gambar 3.

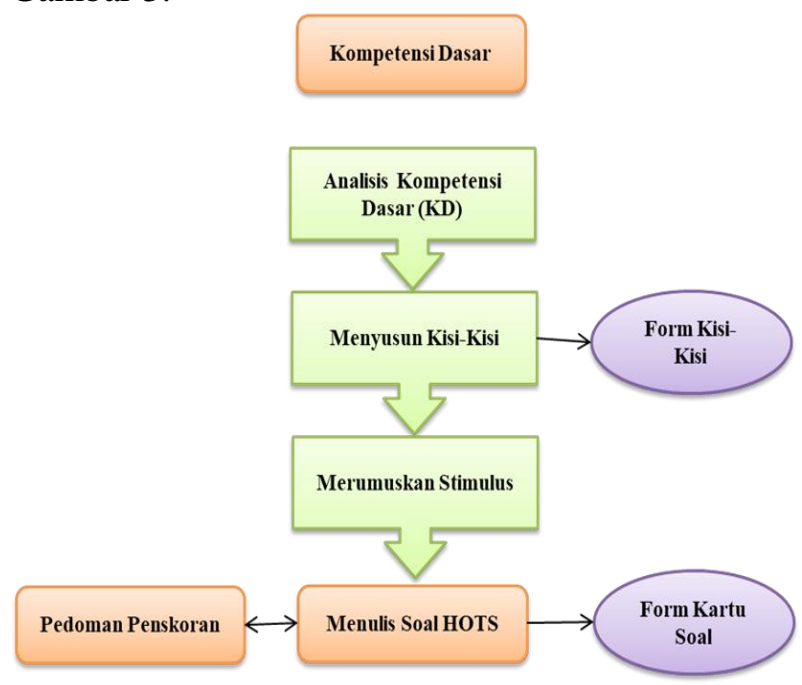

Gambar 3. Langkah-langkah Penyusunan Soal

Keterampilan Berpikir Tingkat Tinggi

Pada akhir pelatihan dibagikan angket terkait dengan respon peserta terhadap penyampaian materi yang telah dilakukan dan rencana tindak lanjut kegiatan pelatihan. Respon dari peserta pelatihan menunjukkan bahwa penyampaian materi pelatihan mudah dipahami dan semua guru menyatakan perlu mengembangkan soal-soal yang berorientasi HOTS. Disamping itu, dalam pengembangan soal-soal HOTS perlu dilakukan pendampingan pada guru. Hasil pendampingan dapat dilakukan dengan membuat buku panduan pembuatan soal HOTS dan pendampingan melalui kegiatan MGMP. Karena itu setelah kegiatan pelatihan ini, dibuatkan buku panduan oleh tim dan diberikan kepada guru khususnya guru-guru biologi yang ada di Kabupaten Lombok Barat. Hasil pendampingan yang dilakukan dengan menggunakan buku panduan menunjukkan bahwa 60\% guru masih mengalami kesulitan dalam membuat soal HOTS. Faktor yang menyebabkan kesulitas ini diantaranya ialah waktu dan kemampuan guru dalam membuat stimulus.

Stimulus dalam pembuatan soal HOTS harus menarik, memiliki unsur kebaruan, dan belum pernah dibaca oleh siswa, atau isu-isu yang sedang mengemuka. Disamping itu, stimulus merupakan suatu bentuk kenyataan yang terjadi dalam kehidupan sehari-hari. Beberapa hal yang perlu diperhatikan untuk menyusun stimulus soal HOTS: (1) pilihlah beberapa informasi dapat berupa gambar, grafik, tabel, wacana, dan lain-lain yang memiliki keterkaitan dalam sebuah kasus; (2) stimulus hendaknya menuntut kemampuan menginterpretasi, mencari hubungan, menganalisis, menyimpulkan, atau menciptakan; (3) pilihlah kasus/permasalahan konstekstual dan menarik (terkini) yang memotivasi siswa untuk membaca (pengecualian untuk mapel Bahasa, Sejarah boleh tidak kontekstual); dan (4) terkait langsung dengan pertanyaan (pokok soal), dan berfungsi. Pada saat pembuatan stimulus ini, guru mengalami kesulitan yang terkait dengan kemampuan literasi dasar sekitar $30-40 \%$ dan kesulitan dalam melakukan kegiatan pengembangan media sekitar 50\%.

Pemberian pelatihan dan pendampingan melalui buku pedoman yang dibagikan pada guru masih dirasakan belum cukup efektif dalam membantu guru mengembangkan soal-soal yang berorientasi HOTS. Karena itu kegiatan pelatihan dan pendampingan ini masih harus dilanjutkan dengan menggunakan forum MGMP untuk membuat program secara reguler terkait dengan pembuatan soal-soal yang berorientasi HOTS. Namun demikian, pendampingan dari narasumber yang berasal dari perguruan tinggi dan atau dinas instansi terkait seperti LPMP masih sangat dibutuhkan.

\section{Kesimpulan}

Hasil kegiatan pelatihan dan pendampingan pada guru biologi dalam mebuat instrumen penilaian HOTS yang ada di Kabupaten Lombok Barat menunjukkan bahwa guru-guru biologi yang ada di Kabupaten Lombok Barat masih mengalami kesulitan dalam pembuatan stimulus. Faktor 
penyebab guru mengalami kesulitan diantaranya disebabkan oleh kemampuan literasi dasar sekitar $30-40 \%$ dan kesulitan dalam melakukan kegiatan pengembangan media sekitar 50\%. Karena itu, kegiatan pendampingan lanjutan yang melibatkan forum MGMP masih diperlukan. Kegiatan pendampingan lanjutan ini sangat diharapkan dari perguruan tinggi dan LPMP.

\section{Ucapan Terima Kasih}

Terimakasih yang sebesar-bearnya disampaikan kepada FKIP Universitas Mataram yang telah memberikan fasilitas pendanaan kegiatan pengabdian ini melalui dana PNBP TA 2020. Ucapan terimakasih disampaikan juga kepada ketua MGMP Lombok Barat Bapak Ismawan Hariadi, M.Pd dan Bapak Dr. I Wayan Widana, M.Pd. sebagai narasumber yang banyak membantu dalam memfasilitasi guru-guru biologi mengikuti kegiatan pelatihan.

\section{Daftar Pustaka}

Anderson, L.W., \& Krathwohl, D.R. 2001. A Taxonomy for Learning, Teaching, and Assesing: A Revision of Bloom's Taxonom $y$ of Educational Objectives. New York: Addison Wesley Longman, In.

Devi, P. K.(2012).Pengembangan soal Higher Order Thinking Skill dalam Pembelajran IPA SMP/MTs. Jurnal Pendidikan IPA (2) $2: 32-40$.

Hadiprayitno, G., Muhlis, \& Kusmiyati. 2019. Problems in learning biology for senior high schools in Lombok Island. J. Phys.: Conf. Ser. 1241012054.

Hanifah, N. 2019. Pengembangan instrumen penilaian Higher Order Thinking Skill (HOTS) di sekolah dasar. Current Research in Education: Conference Series Journal (1) 1: 1 - 8 .

Kemendikbud. 2017. Modul penyusunan soal HOTS. Jakarta: Direktorat Pembinaan SMA.

Kemendikbud. 2018. Higher Order Thinking Skills (HOTS) Konsep dan Penilaian. Jakarta. Pusat Penilaian Pendidikan. Badan
Penelitian dan Pengembangan Pendidikan, Kementerian Pendidikan dan Kebudayaan.

Wahyuningtyas, N., \& Ratnawati, N. 2018. Workshop pengembangan soal HOTS bagi guru-guru MGMP IPS Kabupaten Malang. Jurnal Praksis dan Dedikasi Sosial (1) 2: $73-79$.

Zaini, M. 2015. Hasil belajar dan keterampilan berpikir tingkat tinggi siswa SMA pada pembelajaran biologi menggunakan model pembelajaran berdasarkan masalah. Jurnal Pendidikan Biologi (20) 207. 